\title{
Role of Galectin-1 in the Olfactory Nervous System
}

\author{
嗅神経系でのガレクチン-1の役割
}

\author{
Key, Brian* ; and Puche, Adam C. \\ Laboratory of Molecular Neurodevelopment, Department of Anatomy and Cell Biology, \\ University of Melbourne, Parkville, 3052, Australia \\ Fax:61- 3-9347-4190, E-mail: bkey@anatomy.unimelb.edu.au
}

Key Words: axon growth, carbohydrate, development, lectin, olfaction

\begin{abstract}
The olfactory nervous system is responsible for the detection of odors. Primary sensory olfactory neurons are located in a neuroepithelial sheet lining the nasal cavity. The axons from these neurons converge on to discrete loci or glomeruli in the olfactory bulb. Each glomerulus consists of the termination of thousands of primary axons on the dendrites of second-order olfactory neurons. What are the molecular mechanisms which guide growing olfactory axons to select sites in the olfactory bulb? We have shown that subpopulations of these axons differentially express cell surface carbohydrates and that these different subpopulations target and terminate in particular regions of the olfactory bulb. Interestingly, the olfactory neurons and glial components in the olfactory pathway between the nose and brain express galectin-1. By using in vitro assays of neurite outgrowth we found that both galectin-1 and it's ligands were capable of specifically stimulating neurite elongation. Examination of the olfactory system in galectin- 1 null mutants revealed that a subpopulation of axons failed to navigate to their target site in the olfactory bulb. This is the first phenotypic effect observed in galectin-1 null mutants and indicates that galectin- 1 has a role in the growth and/or guidance of a subpopulation of axons in the olfactory system during development.
\end{abstract}

\section{A. Introduction-Why Study the Olfactory System?}

Primary sensory olfactory neurons are located in a peripheral neuroepithelium lining the dorsocaudal surface of the nasal cavity (Fig. 1). The axons of these neurons course along the olfactory nerve, enter the central nervous system and form topographically organized synapses in the olfactory bulb, a rostral extension of the telencephalon. These axons coalesce into bundles or fascicles in the submucosa and are ensheathed by fibres of olfactory nerve ensheathing cells (Fig. 1). In the olfactory bulb the primary olfactory olfactory axons enter an outer nerve fibre layer and then terminate on the dendrites of mitral cells in specialized globules of synaptic connections called

* Author for correspondence

\section{要 約}

「におい」は嗅神経系により検出される。1次嗅細胞は鼻腔 を㧍㧍っている嗅上皮上にある。嗅細胞からでている軸索は、嗅 球内の糸球体の別々の部位に収束している。おのおのの糸球体 では何千もの1次嗅細胞の終末が、2次嗅細胞の樹状突起とシナ プスを形成する。嗅細胞から軸索が伸びて嗅球の特定の部位に 導かれるのは、どのような分子メカニズムによるのだろうか。軸 索の各集団が表面に特異的な糖鎖を発現して、嗅球の特定の部 位に向かって伸びていって終結する。おもしろいことに、鼻と 脳の間の嗅伝達系の嗅細胞やグリア細胞はガレクチン-1を発現 している。神経突起伸展の in vitroアッセイ系を用いて、我々は ガレクチン -1 とそのリガンドの両方が、神経突起伸展を特異的 に促進できることを見出した。ガレクチン - 1 を欠失した変異体 の嗅覚系を調べると、特定の軸索が嗅球の目的の部位へ到達で きないことがわかった。これはガレクチン -1 欠失変異体で初め て見出された表現型であり、ガレクチン -1 が発生において、嗅 覚系の特定の軸索の伸展·誘導に働いていることを示している。

A. はじめに - なぜ嗅覚系を調べたのか ?

1次嗅細胞は鼻腔の背尾側表面をおおう拈っている末梢感覚上 皮に存在している(図 1)。このニューロンの軸索は嗅神経に沿っ て進み、中枢神経系に入り、終脳からくちばし状に伸びている 嗅球のところで、組織的なつながりを持つシナプスを形成する。 軸索は粘膜下組織で束を作り、嗅神経鞘細胞 $(E C)$ の繊維によ り覆われる (図1)。嗅球では、1次嗅細胞の軸索が外側の神経瀻 維層に入り、糸球体 (シナプス結合をするように分化した小球) に存在する僧帽細胞の樹状突起とシナプスを形成して止まる。1 つの糸球体に入っていく嗅細胞の軸索は、鼻腔の広い領域に散 


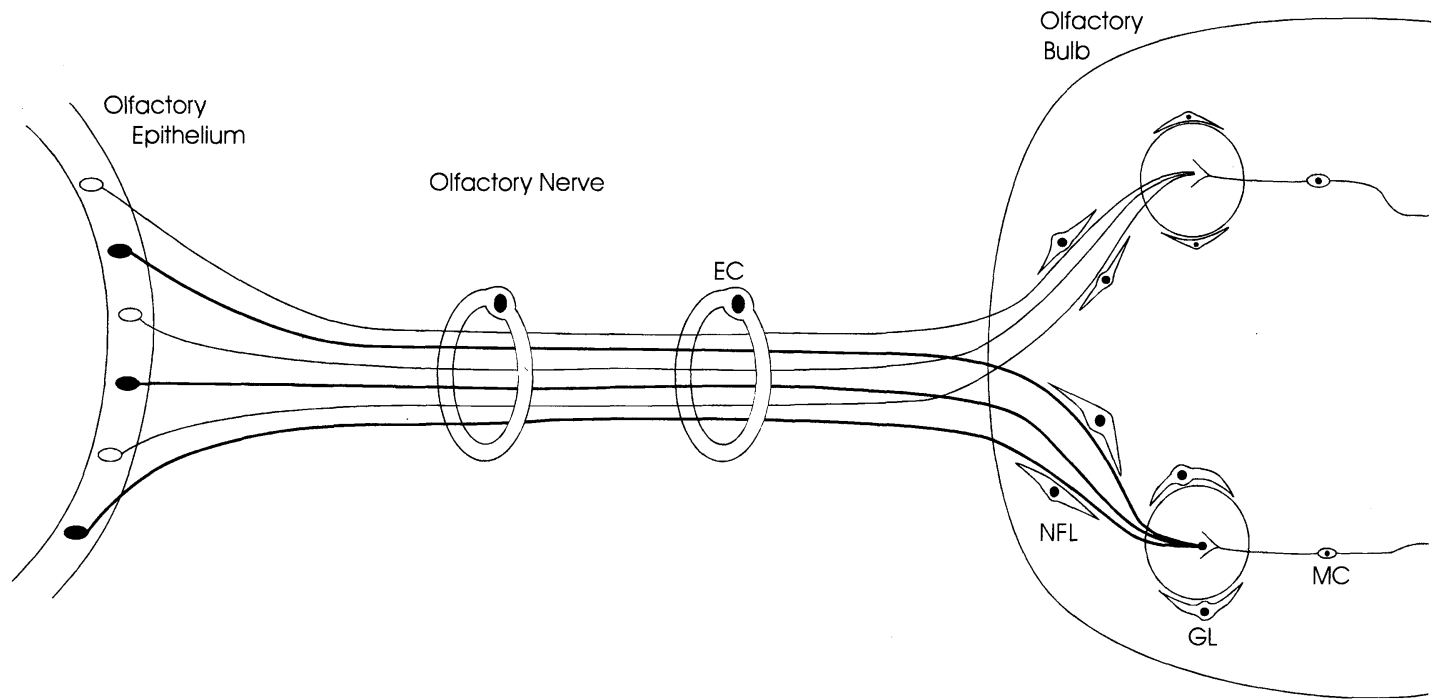

Fig. 1. Diagrammatic representation of the olfactory nervous system. The olfactory epithelium (OE) lines the nasal cavity and contains the perikarya of the primary olfactory neurons. There are discrete subpopulations of these neurons which express distinct cell surface carbohydrates (depicted here by dark and light perikarya). The axons of these neurons course in the olfactory nerve ensheathed by special glia, the ensheathing cells (EC). The different axon subpopulations sort out in the outer layer of the olfactory bulb, the nerve fibre layer (NFL), before terminating on the dendrites of mitral cells (MC) in select glomeruli (GL). Ensheathing cells are present around axon fascicles in the NFL and periglomerular cells and astrocytes encapsulate glomeruli.

glomeruli. The olfactory axons innervating a single glomerulus arise from neurons scattered over a wide region of the nasal cavity (Treloar et al.,1996a). During development and in the mature olfactory system growing primary olfactory axons must converge onto specific target sites from widely disparate origins.

\section{B. What Are the Axon Guidance Molecules in the Olfac- tory Nerve Pathway?}

Although the olfactory neuroepithelium essentially consists of a homogeneous class of primary sensory neurons, there are numerous subpopulations of olfactory neurons expressing chemically distinct phenotypes. In particular, numerous subpopulations have been characterized by expression of unique carbohydrate residues using plant lectins and monoclonal antibodies (Mori, 1993; Key and Giorgi, 1986). Some of these cell surface carbohydrates have been implicated in axon guidance because they define subpopulations of neurons whose axons converge and target specific glomeruli in the olfactory bulb (Key and Akeson, 1993; Puche and Key, 1996). One subpopulation of mouse primary olfactory neurons expressed cell surface $\mathrm{N}$-acetyl-galactosamine, which was recognized by the plant lectin Dolichos biflorus agglutinin (DBA). These neurons were widely dispersed in the nasal cavity and yet innervated glomeruli located predominantly in the rostral and dorsocaudal olfactory bulb. The axons of this DBA-stained subpopulation of neurons were randomly dispersed in the olfactory nerve fascicles and only began to selectively sort out and self-fasciculate
らばっている多くの嗅細胞に由来する (Treloar et al., 1996b)。発 生の途上でも、成熟した嗅覚系でも、嗅神経の軸索は広い範囲 から出発して伸展してゆき、特異的な標的部位に集合しなけれ ばならない。

\section{B. 嗅伝達系における軸索誘導分子は何か？}

嗅上皮は基本的には均一な 1 次嗅細胞でできているが、化 学的には異なった表現型を示す多数の集団に分けることができ る。特に固有の糖構造を発現している集団が、植物レクチンや モノクローナル抗体を用いていくつも解析されている (Mori, 1993; Key and Giorgi, 1986)。軸索の誘導に関与している細胞表 面糖鎖もある。なぜなら、どの嗅細胞の軸索が集合して嗅球の 特定の糸球体に向かっていくのかが、発現している糖鎖によっ て決まるからである (Key and Akeson, 1993 ; Puche and Key, 1996)。マウスの1次嗅細胞には、細胞表面にN-アセチルガラク トサミンを発現しているものがある。これは植物レクチン Dolichos biflorus凝集素 (DBA) が認識する。この咱細胞は鼻腔 に広く分布し、さらに、嗅球の吻側と背尾側に主に存在する糸 球体を支配する。DBAで染まる神経細胞の軸索は、嗅神経の小 束内にランダムに分散しているが、神経支配しょうとしている 系球体直前の嗅球神経繊維層で初めて集合し、まとまった束を 
in the nerve fibre layer of the olfactory bulb prior to innervating glomeruli. These observations indicate that the nerve fibre layer is an important decision point for growing axons in the olfactory nerve pathway. The self-fasciculating behaviour of axons expressing cell surface $\mathrm{N}$-acetyl-galactosamine led us to hypothesis the presence of endogenous galectins in the olfactory nerve fibre layer.

\section{The Search for Galectin-I in the Olfactory System}

We adopted a reverse transcriptase-polymerase chain reaction (RT-PCR) approach in an initial screen for the expression of galectins in the olfactory bulb. Degenerate oligonucleotides for two conserved regions in the galectin family of lectins were used as primers in RT-PCR from mRNA extracted from adult rat olfactory bulb. This analysis revealed that galectin-1 was expressed in the olfactory bulb. The full-length coding region of galectin- 1 was then cloned from the olfactory bulb and used to generate biotinylated RNA transcripts for in situ hybridization. Galectin-1 was widely expressed in the rat olfactory system; galectin-1 mRNA was detected in primary olfactory neurons in the olfactory neuroepithelium, in olfactory Schwann cells in the olfactory nerve and olfactory nerve fibre layer and in post-synaptic mitral cells in the olfactory bulb (Puche and Key, 1995). Immunostaining revealed that galectin-1 was present in the extracellular matrix surrounding nerve fibre bundles and in and around the glomerular layer of the olfactory bulb (Puche and Key, 1995). We predicted that galectin-1 was involved in cross-linking axons expressing appropriate cell surface ligands to the extracellular matrix (Treloar et al., 1996b) in the olfactory nerve fibre layer. These axons would then serve as a template for fasciculation of other axons which express ligands and secrete the bivalent galectin1. A role for galectin-1 in adhering olfactory neurons to laminin and in facilitating cell-cell adhesion was confirmed in vitro (Mahnthappa et al., 1994).

In a search for putative ligands in the olfactory pathway we found that a subpopulation of primary olfactory neurons express cell surface lactosamine (Puche and Key, 1996). The axons of these neurons coursed randomly in the olfactory nerve and only sorted out and selectively fasciculated in the olfactory nerve fibre layer of the olfactory bulb. Interestingly, substratebound lactosamine specifically stimulated neurite growth by cultured primary olfactory neurons (Puche and Key, 1996). This neurite-outgrowth promoting activity was specific for lactosamine since other substrate-bound sugars, such as fucose, which is also expressed by olfactory neurons, had no effect on neurite growth. These observations suggested that sugargalectin-1 interactions may be actively involved in stimulating axon growth within the olfactory nerve pathway. Subsequent analysis of neurite outgrowth by mouse sensory olfactory neuron cell lines have demonstrated that either substrate-bound
形成する。この結果から、嗅神経経路を伸展中の軸索にとって、 神経繊維層が重要な分岐点になることが示された。細胞表面に N-アセチルガラクトサミンを発現している軸索が自ら束を作る 現象から、我々は内在性のガレクチンが嗅神経繊維層に存在し ているという仮説を立てた。

\section{C. 嗅神経系におけるガレクチン-1の検索}

嗅球に㧍けるガレクチンの発現を調べるため、まず最初に、 RT-PCR を行った。ガレクチン分子内の保存性の高い領域 2 籄 所に対応する縮重オリゴヌクレオチドを RT-PCR のプライマー に用いた。mRNAは成体ラットの嗅球より抽出した。嗅球には ガレクチン -1が発現していた。嗅球からガレクチン -1の翻訳領 域全長がクローニングされ、それをもとにRNAをビオチン化標 識し、in situハイブリダイゼーションに用いた。ガレクチン-1は ラットの嗅覚系に広く発現されていた。ガレクチン -1 のRNA は、(i) 感覚上皮の 1 次嗅細胞、(ii) 嗅神経及び嗅神経瀻維層の シュワン細胞、(iii) 嗅球内のポストシナプス僧帽細胞で検出さ れた (Puche and Key, 1995)。免疫染色を行うと、ガレクチン -1 は神経繊維の束を囲んでいる細胞外マトリックスや嗅球の糸球 体層の周囲に存在していた (Puche and Key, 1995)。嗅神経瀻維 層では、適当な細胞表面リガンドを発現している軸索を、ガレ クチン -1 が細胞外マトリックスに架橋しているらしい (Treloar et al., 1996a)。この軸索が鋳型となって、他の軸索でリガンドを 発現し、かつ 2 価のガレクチン -1 を分泌するものが束になって いくのだろう。ガレクチン-1が嗅細胞をラミニンへ接着させ、細 胞と細胞の接着を促進することは in vitroで確認されている (Mahanthappa et al., 1994)。

嗅覚の神経伝達系に存在するガレクチンリガンドを探して いるうちに、1次嗅細胞で細胞表面にラクトサミン構造を発現し ているグループがあることがわかった(Puche and Key, 1996)。こ の嗅細胞の軸索はランダムに走っているが、嗅球の嗅神経繊維 層のところで初めてょり分けられて選択的に束になる。おもし ろいことに、初代培養嗅細胞で実験すると、基質に結合したラ クトサミンが神経突起伸展を特異的に刺激する (Puche and Key, 1996)。この神経突起伸展促進作用はラクトサミン特異的であっ た。嗅細胞で発現されているフコースなどの他の糖を基質に結 合させて扔いても全く効果がなかったからである。この結果か ら、細胞表面の糖鎖と基質に結合している糖鎖とを架橋する夕 ンパク質としてガレクチン -1が働き、嗅神経において軸索の伸 展を促進していることが示唆された。ガレクチン -1のin vivoの リガンドは不明であるが、ラクトサミンもその候補である。マ ウスの嗅神経細胞株を用いた実験では、基質に結合したラクトー 
lactose or recombinant galectin-1 stimulates neurite outgrowth (Puche et al., 1996) by activating specific transmembrane signalling pathways (Puche and Key, unpublished observations). Thus, ligands for galectin- 1 on primary olfactory neurons appear to have a dual ligand/receptor function because of their ability to stimulate intracellular signalling mechanisms.

\section{Abnormal Topography of Olfactory Axons in Galectin-1 Null Mutant Mice}

To identify the in vivo role of galectin- 1 in the olfactory system we next analysed the olfactory nerve pathway in transgenic null mutant mice lacking the galectin-1 gene (Poirier and Robertson, 1993). In these mice the gross morphology of the olfactory system was unaffected; there was a normal complement of primary olfactory neurons in the nasal cavity and the axons of these neurons projected normally to the olfactory bulb and formed glomeruli as in control wild-type animals (Puche et al., 1996). However, the galectin-1 null mutants exhibited a clear defect in the topography of connections between the nasal cavity and the olfactory bulb. A subpopulation of DBA-stained primary olfactory neurons failed to target glomeruli located in the dorsocaudal aspect of the olfactory bulb. These results demonstrated that the growth and/or guidance of a small subpopulation of olfactory axons was selectively mediated by galectin-1. Some axons, expressing high affinity ligands for galectin-1, probably failed to selectively fasciculate upon entering the nerve fibre layer and become lost en route to their target sites in the caudal regions of the olfactory bulb. This is the first demonstration of the involvement of galectin-1 in axon growth and/or guidance in the mammalian nervous system. Future studies will be directed toward identifying the ligands for galectin-1 in the olfactory nerve pathway and characterizing the molecular basis of transmembrane signalling activated by galectin- 1 .

Received on September 24, 1996, accepted on October 7, 1996
スや組み換えガレクチン -1 が、特異的な膜貫通型のシグナル伝 達経路を活性化して (Punche and Key, 未発表デー夕) 神経突起 の伸展を刺激した (Puche et al., 1996)。1 次嗅細胞上のガレクチ ン-1リガンドは、細胞内シグナル伝達系を刺激することから、リ ガンドとしての役割と、シグナル伝達レセプターとしての両方 の役割を持つようである。

\section{D. ガレクチン -1 欠損マウスの嗅神経軸索の形態異常}

ガレクチン-1が嗅覚系でどのような役割を果たしているか を in vivoで確かめるため、我々は引き続いて、ガレクチン -1 を 欠いたトランスジェニックマウス (Poirier and Robertson, 1993) の嗅神経系を解析した。このマウスでは、嗅神経系のおおゔっ ぱな形態は変わっていなかった。鼻腔における1次嗅細胞の数 も正常であったし、軸索は嗅球に向かって正常に伸びていって おり、コントロールの野生型マウスと同様、糸球体を形成して いた (Puche et al., 1996)。しかし、ガレクチン -1 欠損マウスで は、鼻腔と嗅球の間の結合の形態が明らかに異常であった。DBA で染まる 1 次嗅細胞が、嗅球の背尾側の糸球体に向かって伸び ていくことができなかったのである。嗅神経の集団の中には、軸 索の成長·誘導において選択的にガレクチン -1 を介しているも のもあるらしい。ガレクチン -1 欠損マウスでは、ガレクチン -1 に親和性が高いリガンドを発現している軸索が、神経繊維層に 入る際に選択的に束になることができず、嗅球の尾側の標的部 位に向かう途中で迷ってしまうものがでてくるのだろう。

この結果は、哺乳動物の神経系において、軸索の成長・誘 導におけるガレクチン-1の関与を示した最初の例である。今後 は、嗅神経におけるガレクチン -1のリガンドの同定と、ガレク チン-1によって活性化される膜貫通型のシグナル伝達経路の分 子レベルでの解析に向けて研究を進める予定である。

帝京大学薬学部生物化学教室

荒田 洋一郎 訳 


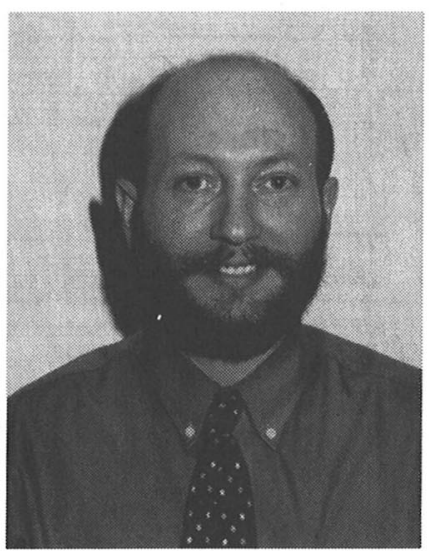

\section{Brian Key} Qualifications:

Bachelor of Human Movement Studies, University of Queensland (1983). Doctor of Philosophy,University of Queensland (1988)

Present Appointment: Senior Lecturer, Department of Anatomy and Cell Biology,University of Melbourne.

Society Memberships: Australian Neuroscience Society, Australian and New Zealand Society for Cell and Developmental Biology, American Neuroscience Society.

Honours: Victorian Representative of Australian \& New Zealand Society for Cell \& Developmental Biology, President-Elect of Australian \& New Zealand Society for Cell \& Developmental Biology, Member of Editorial Advisory Board of International Journal of Developmental Biology, Member of the Editorial Board of the International Journal of Developmental Neuroscience.

\section{Recent Publications:}

1. Anderson, R.A. and Key, B. (1996) Expression of NOC1, a novel N-CAM glycoform, on subsets of axon tracts in the embryonic Xenopus nervous system. Dev. Dynamics, 207, 263-269.

2. Puche, A.C., Poirier, F., Hair, M., Bartlett, P. and Key, B. (1996) Role of galectin-1 in the developing mouse olfactory system. Dev. Biol., 179, 274-287.

3. Puche, A.C. and Key, B. (1996) N-acetyl-lactosamine in the rat olfactory system: expression and potential role in neurite growth. J. Comp. Neurol., 364, 267-278.
4. Key, B. and Puche, A.C. (1997) Role of galectin-1 in development of the olfactory system. Trends Glycosci. Glycotech. 9 (in press).

5. Key, B., Treloar, H.B., Wangerek, L., Ford, M.D. and Nurcombe, V. (1996) Expression and localization of FGF1 in the developing rat olfactory system. J. Comp. Neurol., 366, 197-206.

6. Treloar, H.B., Walters, T., Margolis, F. and Key, B. (1996) Olfactory glomeruli are innervated by more than one distinct subset of primary sensory olfactory neurons in mice. J. Comp. Neurol. 367, 550-562.

7. Treloar, H.B., Nurcombe, V. and Key, B. (1996) Expression of extracellular matrix molecules in the embryonic rat olfactory pathway. J. Neurobiol. 31, 41-55.

8. Small, D.H., Clarris, H.L., Williamson, T.G., Reed, G., Key, B., Mok, S.S., Beyreuther, K., Masters, C.L. and Nurcombe, V. (1996) Trophic functions of the amyloid protein precursor of Alzheimer's disease. Alzheimer's Disease Review 1,1-9.

9. Cauchi, J., Alcorn, D., Cancilla, B., Key, B., Berka, J.L., Nurcombe, V., Ryan, G.B. and Bertram, J.F. (1996) Light microscopic immunolocalization of fibroblast growth factor- 1 and -2 in adult rat kidney. Tissue Cell Res. 285, 179 187.

10.Cancilla, B., Cauchi, J., Key, B., Nurcombe, V., Alcorn, D. and Bertram, J. (1996) Immunolocalization of fibroblastic growth factor- 1 and -2 in the embryonic rat kidney. Nephrology, 2, 167-1754.

11. Key, B. (1996) Molecular and cellular bases of axon guidance in the olfactory system. Int. J. Dev. Biol. (invited review).

12. Key, B. (1996) Membrane and in situ hybridization: principles and pitfalls. In “A Beginner's Guide to Neuroscience Methods” ed. R. Martin, Harwood Publishers, Sydney (in press). 